\title{
RANCANG BANGUN ALAT KONTROL PENGISIAN AKI UNTUK MOBIL LISTRIK MENGGUNAKAN ENERGI SEL SURYA DENGAN METODE SEQUENSIAL
}

\author{
Sagita Rochman*) dan Budi Prijo Sembodo*)
}

\begin{abstract}
Abstrak
Dalam proses pengisian aki (charging) dengan sumber listrik yang berasal dari sel surya, tentunya diperlukan sebuah alat kontrol yang berfungsi mengatur sistem pengisian energi listrik yang biasa disebut charge controller atau kontrol pengisian. Pada aplikasinya, kadangkala penggunaan alat kontrol pengisian tersebut masih terdapat kekurangan, diantaranya ialah alat tersebut hanya dapat digunakan untuk pengisian aki dengan tegangan 12 dan 24 volt saja. Sehingga jika digunakan untuk tegangan yang lebih tinggi dari itu, maka diperlukan modifikasi sistem pengisian yang sesuai dengan kebutuhan.

Penelitian ini merupakan studi kasus pada sistem pengisian aki (charging) mobil listrik Bimo Baskoro yang menggunakan sumber listrik dari sel surya. Pada mobil ini terdapat aki dengan total tegangan 48 volt dengan sumber listrik dari panel surya berkapasitas 100 WP. Penelitian ini bertujuan untuk mendapatkan sistem pengisian aki yang efisien. Sistem yang coba diterapkan adalah dengan metode sequensial. Yakni pengisian dengan cara bergantian satu persatu sampai kondisi kapasitas aki penuh dengan dikontrol alat yang telah diprogram untuk bekerja secara otomatis.

Dari hasil penelitian yang telah dilakukan, didapatkan bahwa penggunaan metode ini dapat diaplikasikan untuk kontrol pengisian aki pada mobil listrik Bimo Baskoro dengan keunggulan dapat melakukan pengisian aki 48 volt dengan sumber tegangan 12 volt dari energi listrik yang dihasilkan sel surya.
\end{abstract}

Keyword: Charge, panel surya, metode sequensial

\section{PENDAHULUAN}

Di Fakultas Teknik sedang membuat mobil listrik yang dinamakan Bimo Baskoro. Dalam proses pembuatannya, maka membutuhkan perencanaan serta teknik pengerjaan yang bagus agar diperoleh hasil yang memuaskan.

Sumber energi dari mobil listrik ini ialah tenaga listrik yang disimpan pada aki dan kemudian dikonversikan menjadi tenaga gerak berupa putaran motor yang dikopel untuk memutar roda motor.

Pada proses pengisian aki (charging), sumber energi listrik dari sel surya menghasilkan tegangan 12 volt. Sedangkan jumlah aki yang harus diisi sebanyak 4 buah dengan spesifikasi 12 volt dengan kapasitas $35 \mathrm{Ah}$. Jadi total tegangan yang harus dicharge adalah 48 volt. Sehingga pada proses pengisian aki diperlukan metode yang sesuai karena besar tegangan sumber lebih kecil dari tegangan yang di-charge.

Rumusan masalah

Bagaimanakah unjuk kerja metode sequensial yang digunakan untuk pengisian aki pada mobil listrik Bimo Baskoro?

Tujuan dari penelitian ini adalah :
1. Mendapatkan metode pengisian aki yang sesuai dengan kondisi sumber tegangan yang ada.

2. Membuat alat kontrol pengisi aki untuk dapat digunakan pada studi kasus pengisian aki mobil listrik Bimo Baskoro.

Dari penelitian ini diharapkan dapat memberikan manfaat antara lain:

1. Mendapatkan suatu alternatif teknologi untuk pengisian aki.

2. Mendapatkan sistem kontrol pengisian aki yang dapat dipakai pada mobil listrik Bimo Baskoro.

\section{KAJIAN PUSTAKA}

Mobil Listrik

Beberapa keunggulan mobil listrik:

- Mobil listrik memiliki beberapa keunggulan atas mobil berbahan bakar tradisional. Yang paling jelas dan yang paling sering dibicarakan adalah mobil listrik 100 persen bebas emisi. Hal ini berarti tidak seperti mobil berbahan bakar konvensional lain, mobil listrik tidak memberikan kontribusi terhadap dampak perubahan iklim.

*) Dosen Teknik Elektro Universitas PGRI Adi Buana Surabaya 
- Mobil listrik jauh lebih hemat energi dibandingkan dengan mobil berbahan bakar konvensional. Efisiensi keseluruhan mobil listrik adalah 48 persen, secara signifikan lebih baik dibandingkan dengan mobil berbahan bakar konvensional yang mencapai efisiensi sekitar $25 \%$.

- Tidak seperti mobil tradisional, mesin mobil listrik sangat halus sehingga mereka tidak menyebabkan masalah polusi suara.

- Mobil listrik juga menjamin keamanan maksimum karena tidak melibatkan bahan bakar minyak sehingga mereka tidak akan terbakar atau meledak jika menabrak sesuatu.

- Mobil listrik juga sangat kompak dan nyaman.

- $\quad$ Biaya isi ulang mobil listrik juga sangat terjangkau. Rata-rata mobil listrik memerlukan biaya isi ulang 2 sen per mil dibandingkan dengan 12 sen per mil pada kendaraan berbahan bakar konvensional.

- Masa pakai motor mobil listrik diperkirakan sekitar 90 tahun, jika dikendarai sejauh lima puluh mil per hari.

- Mobil listrik juga memiliki biaya pemeliharaan yang secara signifikan lebih rendah dibandingkan dengan mobil berbahan bakar konvesional karena mobil listrik hanya memiliki sekitar 5 bagian di motornya, dibandingkan dengan mobil tradisional yang memiliki ratusan komponen dalam mesin pembakaran internal.

Mobil listrik juga memiliki beberapa kelemahan dan berikut adalah beberapa di antaranya:

- Harga baterai mobil listrik masih tinggi. Baterai yang mahal ini masih menjadi alasan utama di balik tingginya harga mobil listrik secara keseluruhan.

- Fakta bahwa mobil listrik tidak bersuara saat hidup tak selalu merupakan suatu keuntungan karena senyapnya suara mobil bisa menimbulkan bahaya bagi orang buta, orang tua dan anak-anak.

- Tipe mobil listrik masih terbatas dan juga mengisi ulang daya secara signifikan lebih lama dibandingkan dengan proses yang relatif cepat pada pengisian bahan bakar ke tangki pada mobil tradisional.
- Mobil listrik yang digunakan dalam iklim yang lebih dingin memerlukan banyak energi untuk memanaskan interior dan defrost jendela. Pada kendaraan yang menggunakan BBM, proses pembakaran sudah mentransfer panas dari mesin, sedangkan pada mobil listrik pemanas membutuhkan energi ekstra dari baterai mobil.

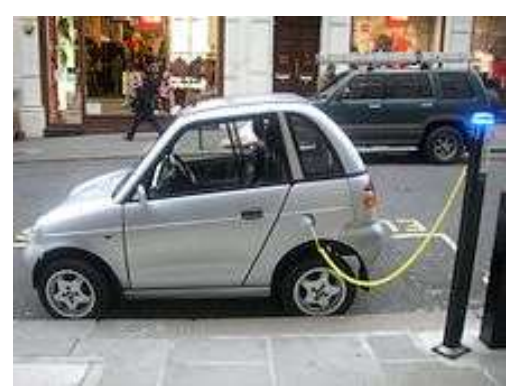

Gambar 1. Mobil listrik REVAi/G-Wiz i sedang mengisi baterai di tempat pengisian listrik di pinggir jalan kota London.

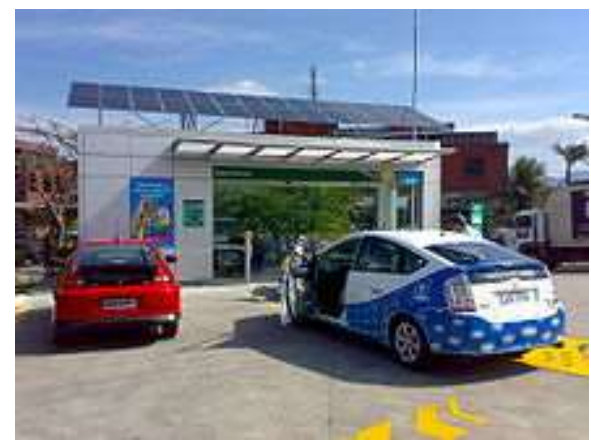

Gambar 2. Stasiun pengisian baterai di Rio de Janeiro, Brasil. Stasiun ini dioperasikan oleh Petrobras dan menggunakan energi surya.

\section{Akumulator / Aki}

Akumulator (accu, aki) adalah sebuah alat yang dapat menyimpan energi (umumnya energi listrik) dalam bentuk energi kimia. Contoh-contoh akumulator adalah baterai dan kapasitor.

Pada umumnya di Indonesia, kata akumulator (sebagai aki atau accu) hanya dimengerti sebagai "baterai" mobil. Sedangkan di bahasa Inggris, kata akumulator dapat mengacu kepada baterai, kapasitor, kompulsator, dll. Di dalam standar internasional setiap satu cell akumulator memiliki tegangan sebesar 2 volt. sehingga aki 12 volt, memiliki 6 cell sedangkan aki 24 volt memiliki 12 cell.

Aki merupakan sel yang banyak kita jumpai karena banyak digunakan pada 
sepeda motor maupun mobil. Aki temasuk sel sekunder, karena selain menghasilkan arus listrik, aki juga dapat diisi arus listrik kembali. secara sederhana aki merupakan sel yang terdiri dari elektrode $\mathrm{Pb}$ sebagai anode dan $\mathrm{PbO} 2$ sebagai katode dengan elektrolit $\mathrm{H}_{2} \mathrm{SO}_{4}$

\section{Pengisian Aki / baterai (Charging)}

Listrik yang digunakan untuk mengisi baterai mobil listrik dihasilkan dari banyak sumber; seperti batu bara, hidroelektrisitas, nuklir atau tenaga lainnya. Sumber tenaga terbaharukan seperti sel surya, mikro hidro, atau angin juga dapat digunakan.

Terdapat bermacam-macam metode charging yang bisa digunakan untuk rangkaian charging. Metode tersebut berbeda dalam cara pemberian energi listrik dari catu daya ke accumulator atau batterai. Metode-metode tersebut diantaranya adalah sebagai berikut:

\section{a. Constant voltage}

Pada dasarnya adalah berupa DC power supply biasa. Terdiri dari transformator step down dengan rangkaian penyearah untuk memberikan tegangan DC yang digunakan untuk mengisi batteray. Metode seperti ini sering digunakan pada pengisi daya pada aki mobil murah. Selain itu, batteray Lithium-Ion juga menggunakan metode constant voltage walaupun sering ditambahkan rangkaian yang kompleks untuk melindungi batteray dan penggunanya. b. Constant current

Metode constant current memvariasikan nilai tegangan sehingga didapatkan besarnya arus yang konstan. Metode ini biasanya digunakan untuk mengisi daya pada nikel-cadmiun dan nikelmetal hibrida atau biasa disebut baterai.

\section{Jenis panel surya}

Panel sel surya mengubah intensitas sinar matahari menjadi energi listrik. Panel sel surya menghasilkan arus yang digunakan untuk mengisi baterai.

Panel sel surya terdiri dari photovoltaic, yang menghasilkan listrik dari intensitas cahaya, saat intensitas cahaya berkurang (berawan, hujan, mendung) arus listrik yang dihasilkan juga akan berkurang

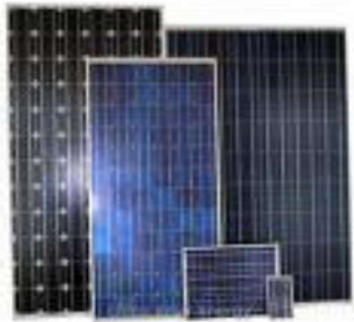

Gambar 3. Berbagai jenis dan ukuran sel surya.

Dengan menambah panel sel surya (memperluas) berarti menambah konversi tenaga surya. Umumnya panel sel surya dengan ukuran tertentu memberikan hasil tertentu pula. Contohnya ukuran a $\mathrm{cm} \times \mathrm{b} \mathrm{cm}$ menghasilkan listrik DC (Direct Current) sebesar $\mathrm{x}$ Watt per hour/ jam.

Jenis panel sel surya:

Polikristal (Poly-crystalline) Merupakan panel surya yang memiliki susunan kristal acak. Type Polikristal memerlukan luas permukaan yang lebih besar dibandingkan dengan jenis monokristal untuk menghasilkan daya listrik yang sama, akan tetapi dapat menghasilkan listrik pada saat mendung.

Monokristal (Mono-crystalline) Merupakan panel yang paling efisien, menghasilkan daya listrik persatuan luas yang paling tinggi. Memiliki efisiensi sampai dengan 15\%. Kelemahan dari panel jenis ini adalah tidak akan berfungsi baik ditempat yang cahaya mataharinya kurang (teduh), efisiensinya akan turun drastis dalam cuaca berawan.

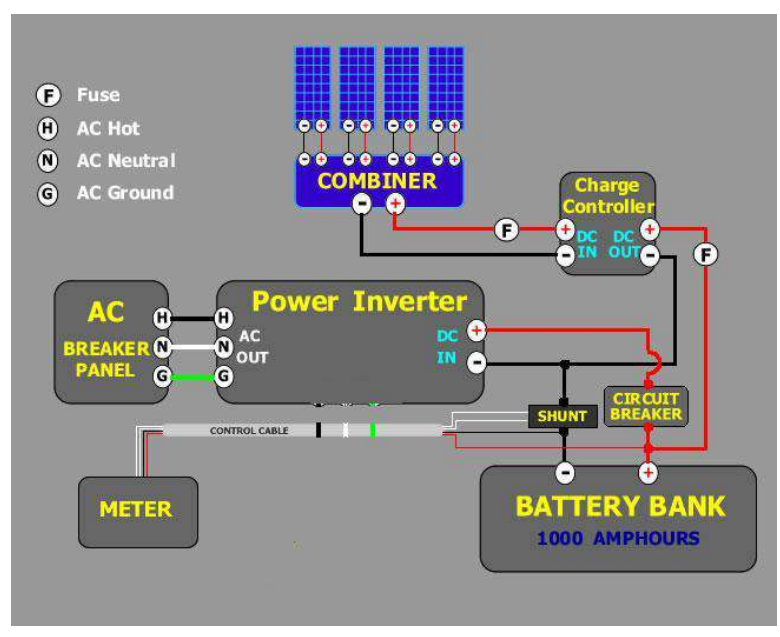

Gambar 4. Skema pengisian aki dengan sumber listrik dari sel surya 


\section{METODE PENELITIAN}

Jenis Penelitian

Penelitian pengembangan yaitu bertujuan untuk menemukan dan mengembangkan suatu prototype baru dalam rangka penyempurnaan dan pengembangan sehingga diperoleh hasil yang lebih produktif, efektif dan efisien (Beni Kurniawan, Metodologi Penelitian, 2012).

\section{Waktu dan tempat}

Penelitian ini dilakukan di laboratoium teknik elektro, fakultas teknik Universitas PGRI Adi Buana Surabaya pada bulan Pebruari 2013 sampai dengan Desember 2013.

\section{Kerangka penelitian}

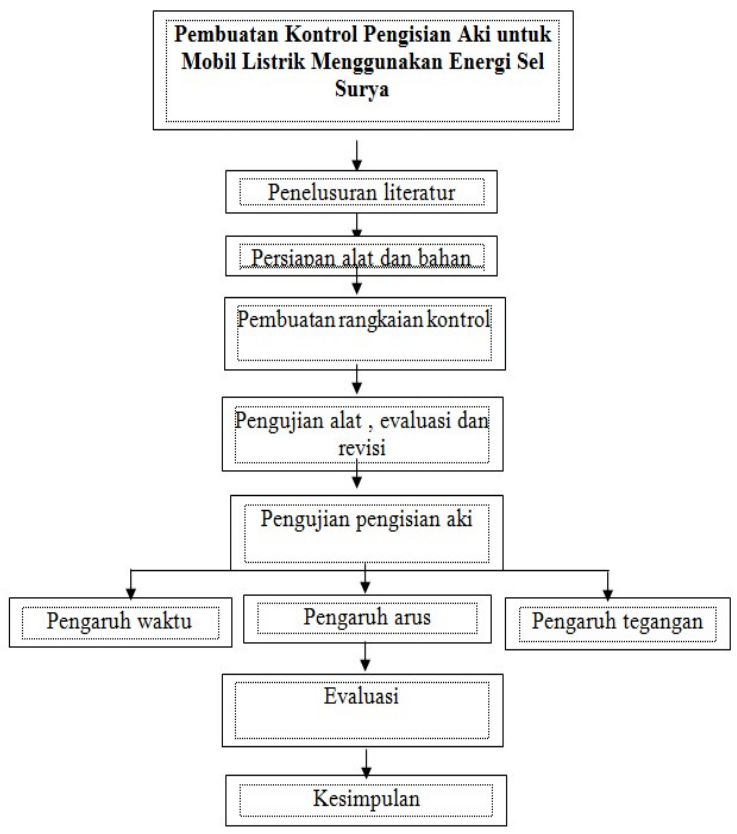

\section{Metode pengumpulan data}

1. Observasi : pengamatan dan pencatatan data-data hasil uji laboratorium

2. Literatur : rancangan alat didasari oleh teori-teori yang relevan

\section{Skema sistem kerja alat}

Skema dasar sistem pengisian aki dengan sumber listrik dari panel surya seperti pada gambar 5\&6 :

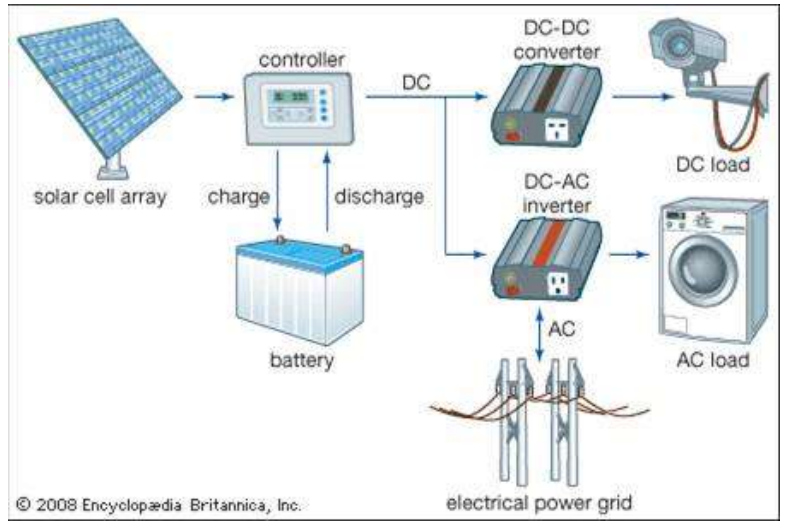

Gambar 5. Skema kontrol pengisian aki untuk 1 aki

Dari gambar skema diatas, pengisian aki diatur oleh controller untuk mengatur tegangan pengisian aki. Output dari kontrol, tegangannya lebih tinggi daripada tegangan aki. Pada penelitian ini digunakan 4 buah aki yang akan di-charge secara bergantian karena tidak memungkinkan di-charge secara bersamaan. Kontroler 1 untuk mengatur tegangan pengisian dari sel surya, sedangkan kontroler 2 untuk mengatur proses sequensial pengisian secara otomatis. Aki di-charge secara bergantian setelah aki sebelumnya terisi penuh.

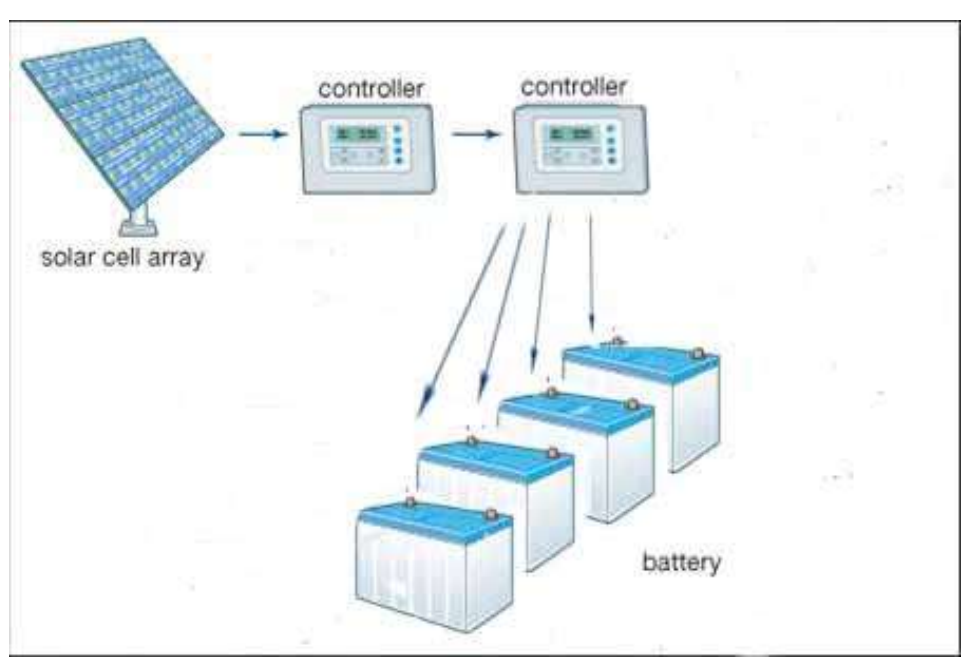

Gambar 6. Skema kontrol pengisian aki untuk 4 buah aki dengan metode bergantian 


\section{Metode analisis data}

Analisis yang digunakan adalah analisis uji laboratorium yaitu untuk mengukur variabel yang telah ditetapkan dengan tahapan sebagai berikut:

1. Menganalisis sistem kerja rangkaian kontrol sistem pengisian aki

2. Menguji rangkaian kontrol sistem pengisian aki

3. Melakukan pengukuran dan evaluasi Pada penelitian ini terdapat beberapa variabel yaitu : tegangan dan arus pengisian (Vin), kapasitas aki (Ah), dan lama waktu pengisian (t).

Variabel bebas $=$ tegangan pengisian

Variabel terikat $=$ lama waktu pengisian

Variabel kontrol $=$ kapasitas aki

Dengan hubungan bahwa:

- Semakin besar tegangan dan arus pengisian, maka waktu pengisian lebih singkat.

- Semakin besar kapasitas aki maka waktu pengisian lebih lama.

\section{HASIL DAN PEMBAHASAN}

Dari hasil pengukuran yang dilakukan, didapatkan data sebagai berikut:

Daya panel surya $=100 \mathrm{WP}$, tegangan output 21,5 volt

Output rangkaian kontrol $=13.5$ Volt, 6 Amper

Kapasitas aki $=12$ volt, $35 \mathrm{Ah}$

Grafik tegangan pada panel surya adalah sebagai berikut :

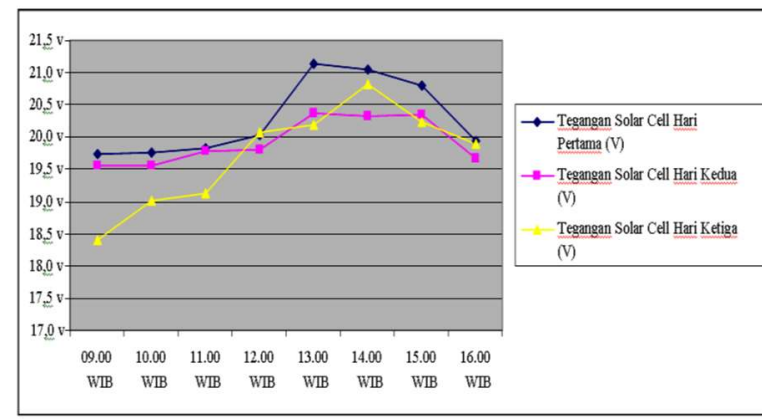

Grafik 1. Tegangan output panel surya bergantung waktu
Pada grafik diatas menunjukkan bahwa mulai pukul 09.00, panel surya sudah dapat digunakan untuk proses pengisian, namun tegangan pada panel surya akan mencapai maksimum pada pukul 12.00 sampai dengan pukul 15.00. karakteristik ini akan mempengaruhi lama waktu pengisian aki sampai penuh.

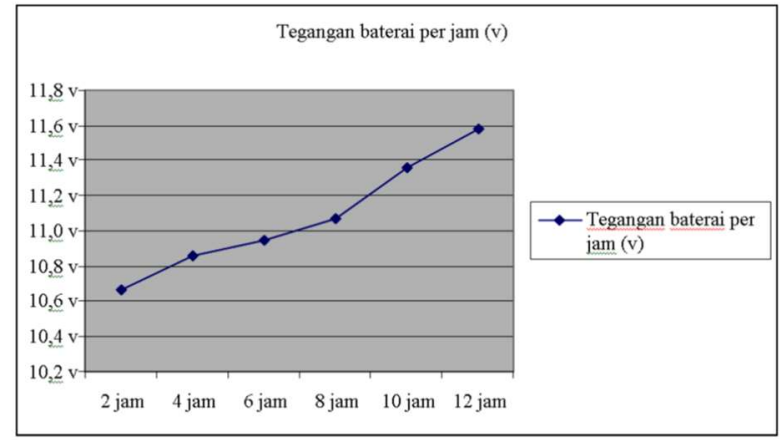

Grafik 2. Kenaikan Tegangan pada aki

Grafik diatas menunjukkan besar tegangan pada aki pada saat proses pengisian dalam selang waktu 12 jam. Tegangan aki semakin naik seiring lama waktu pengisian. Untuk kecepatan naiknya tegangan dipengaruhi beberapa faktor yaitu intensitas cahaya matahari, kapasitas daya panel surya yang digunakan, kemampuan rangkaian kontrol, dan besar kapasitas aki yang di-charge.

\section{SIMPULAN DAN SARAN}

Simpulan

Dari rancang bangun alat kontrol pengisian aki, didapat luaran alat dengan spesifikasi sebagai berikut :

1. Sumber tegangan dari sel surya adalah sebesar 12 volt dengan output 6 amper.

2. Waktu yang dibutuhkan untuk pengisian aki dari kondisi kosong sampai penuh membutuhkan waktu 5 jam.

3. Proses pengisian aki dengan metode sequensial dikendalikan secara otomatis oleh alat kontrol

4. Waktu efektif pada proses pengisian adalah antara pukul 09.00 sampai dengan 16.00 .

5. Arus pengisian maksimum dicapai pada pukul 12.00 sampai 14.00 dengan kondisi cuaca yang cerah.

\section{Saran}

Untuk mendapatkan waktu pengisian yang lebih singkat, maka diperlukan penambahan kapasitas daya dari panel surya yang terpasang. 


\section{DAFTAR PUSTAKA}

Endusa Billy Muhando, Tomonobu Senjyu, Hiroshi Kinjo, Toshihisa Funabashi, "Augmented LQG controller for enhancement of online dynamic performance for WTG system", Renewable Energy 33 (2008)

M. Mohamed Thameem Ansari, S. Velusami, "DMLHFLC (Dual mode linguistic hedge fuzzy logic controller) for an isolated wind diesel hybrid power system with BES (battery energy storage) unit", Energy 35 (2010) 3827-3837

Malvino dan Hanapi Gunawan Diktat Kuliah,Prinsip-Prinsip Elektronik, Edisi Kedua, PT. Gelora Aksara Pratama, Jakarta, 1981.

Muhammad Muhsin, Elektronika Digital-Teori Dan Soal Penyelesaian, Penerbit Andi, Yogyakarta, 2004.

S. Velusami, S. Singaravelu, "Steady state modeling and fuzzy logic based analysis of charge control", Renewable Energy 32 (2007) 2386-2406

Tolga Kaya, Cengiz Kahraman, "Multicriteria renewable energy planning using an integrated fuzzy VIKOR \& AHP methodology: The case of Istanbul", Energy 35 (2010) 2517-2527

Tooley, Mike. 2003. Rangkaian Elektronika Dan Aplikasi. Jakarta: Erlangga.

www.google.com

www.elektro-indonesia.com

Zuhal, Dasar Teknik Tenaga Listrik Dan Elektronika Daya, Gramedia pustaka Utama, Jakarta, Desember 1988. 